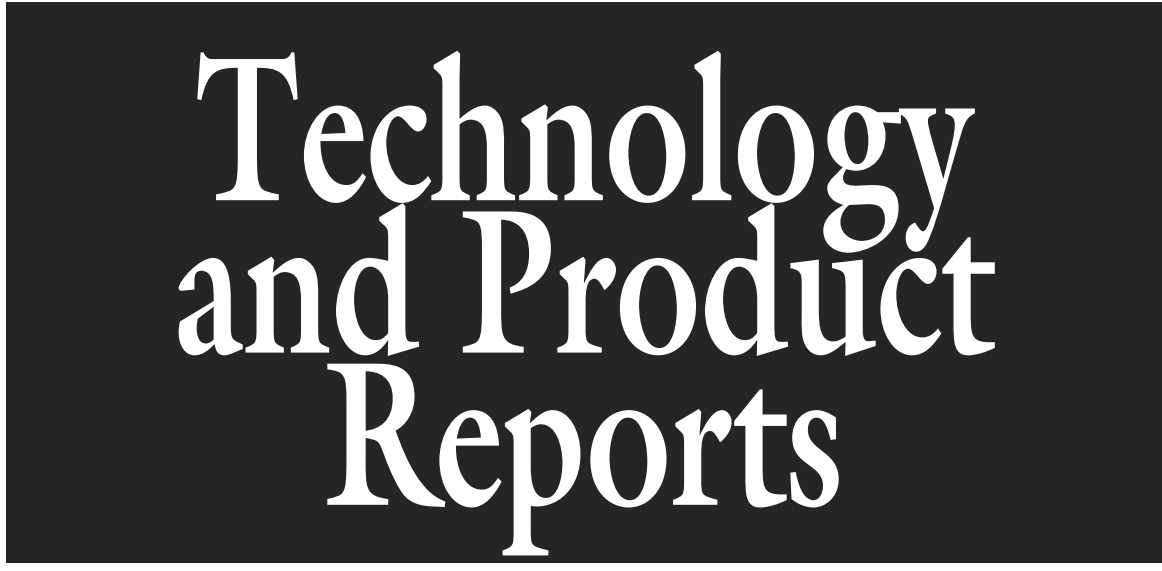

\title{
Preharvest Lipophilic Coatings Reduce Lenticel Breakdown Disorder in 'Gala' Apples
}

\author{
Eric A. Curry ${ }^{1,4}$, Carolina Torres ${ }^{2}$, and Luis Neubauer ${ }^{3}$
}

AdDITIONAL INDEX WORDs. Malus $\times$ domestica, physiological disorder, storage, cuticle, microcracking, wax, lipids, 'Fuji', 'Granny Smith', 'Golden Delicious'

Summary. Lenticel breakdown disorder (LB), most prevalent on 'Gala' (Malus $\times$ domestica) apples, especially in arid regions, has also been observed on other common cultivars. Depending on the preharvest environment, fruit maturity, and length of storage, LB usually appears as one or more round, darkened pits, centered on a lenticel, ranging in diameter from 1 to $8 \mathrm{~mm}$. Symptoms are not visible at harvest nor are they usually apparent on unprocessed fruit after storage. However, following typical fruit processing and packing, symptoms are fully expressed after 12 to $48 \mathrm{~h}$. Because the 3 to 4 weeks preceding 'Gala' harvest are usually the hottest and least humid, we theorized that desiccation stress was a main causative factor. Thus, several unique lipophilic formulations were developed that might reduce desiccation potential during this period of hot arid weather and rapid fruit enlargement. Emulsions of lipophilic formulations were applied to whole trees at various dosages and timings. In 2005, using a single handgun application 1 day before harvest, the best treatment reduced LB by about $20 \%$ in fruit stored 90 days at $-1{ }^{\circ} \mathrm{C}$. The following season, the best treatment from a single handgun application 7 days before harvest reduced LB by $35 \%$ after 90 days at $-1{ }^{\circ} \mathrm{C}$, whereas 3 weekly applications beginning 3 weeks before harvest reduced LB in similarly stored fruit by as much as $70 \%$. In 2007 , the best single treatment applied 1 week before harvest using a commercial airblast sprayer reduced LB by almost $50 \%$ after 90 days at $-1{ }^{\circ} \mathrm{C}$.

T apples, development of physiological disorders is a function of many components, including cultural management, growing environment, fruit maturity, and conditions

\footnotetext{
Mention of a trademark, proprietary product or vendor does not constitute a guarantee or warranty of the product by the U.S. Dept. of Agriculture and does not imply its approval to the exclusion of other products or vendors that also may be suitable.

${ }^{1}$ U.S. Department of Agriculture, Agricultural Research Service, Tree Fruit Research Laboratory, 1104 N. Western Avenue, Wenatchee, WA 98801

${ }^{2}$ PACE International LLC, 5661 Branch Road, Wapato, WA 98951

${ }^{3}$ Pace International LLC, Av. Am. Vespucio N. 2680, Oficina N. 101, Conchali Santiago-Chile, Chile

${ }^{4}$ Corresponding author. E-mail address: eric.curry@ ars.usda.gov.
}

during storage. Disorders related to dysfunctions or aberrations in the development of the epidermal tissue (peel) are often linked to climatic conditions during the growing season and are initiated when a particular metabolic system(s) exhibits stress-induced hysteresis. These include russet, staining, cracking, splitting, flecking, bitter pit, blotch, lenticel marking, radiation injury, delayed sunscald, superficial scald, and soft scald (Meheriuk et al., 1994; Pierson et al., 1971; Porritt et al., 1982). Together, these disorders may render unmarketable as much as $20 \%$ of total production. Considering that the value of apples in Washington state alone in 2006 was \$1.4 billion (National Agricultural Statistical Service, 2007), reducing the loss due to physiological disorders is of significant economic importance.

Since 2000, lenticel breakdown disorder (LB) has been a high priority area for research investigations in the arid apple growing regions of the United States. LB symptoms are not visible at harvest nor are they usually apparent on unprocessed fruit after storage. It is usually after typical fruit processing and packing that symptoms are fully expressed (Fig. 1). Particularly frustrating for the warehouse is that it may take up to $48 \mathrm{~h}$ for LB to appear after fruit have been packed (E.A. Curry, personal observation). If symptoms are detected before shipment, there are often significant repacking costs; if undetected, the negative impact on repeat sales can be lasting.

The distinctive features of LB are: 1) it is not visible at harvest, 2) symptoms on unprocessed fruit in storage are not visible, 3) symptoms are expressed mainly after typical processing (dump tank, washing, waxing, and packing), 4) pitting is round and centered on the lenticel, 5 ) little if any

\begin{tabular}{llll}
\hline $\begin{array}{l}\text { Units } \\
\text { To convert U.S. to SI, } \\
\text { multiply by }\end{array}$ & U.S. unit & SI unit & $\begin{array}{l}\text { To convert SI to U.S., } \\
\text { multiply by }\end{array}$ \\
\hline 1 & $\mathrm{cbar}$ & $\mathrm{kPa}$ & $\mathrm{l}$ \\
29.5735 & $\mathrm{fl} \mathrm{oz}$ & $\mathrm{mL}$ & 0.0338 \\
0.3048 & $\mathrm{ft}$ & $\mathrm{m}$ & 3.2808 \\
3.7854 & $\mathrm{gal}$ & $\mathrm{L}$ & 0.2642 \\
9.3540 & gal $/ \mathrm{acre}$ & $\mathrm{L} \cdot \mathrm{ha}^{-1}$ & 0.1069 \\
2.54 & inch $(\mathrm{es})$ & $\mathrm{cm}$ & 0.3937 \\
25.4 & inch $(\mathrm{es})$ & $\mathrm{mm}$ & 0.0394 \\
6.4516 & inch & $\mathrm{cm}$ & 0.1550 \\
645.1600 & inch & $\mathrm{mm}$ & 0.0016 \\
4.4482 & lbf & $\mathrm{N}$ & 0.2248 \\
1 & micron & $\mu \mathrm{m}$ & 1 \\
1 & $\mathrm{ppm}$ & $\mu \mathrm{L}^{2} \mathrm{~L}^{-1}$ & 1 \\
$\left({ }^{\circ} \mathrm{F}-32\right) \div 1.8$ & ${ }^{\circ} \mathrm{F}$ & ${ }^{\circ} \mathrm{C}$ & $\left(1.8 \times{ }^{\circ} \mathrm{C}\right)+32$ \\
& & &
\end{tabular}



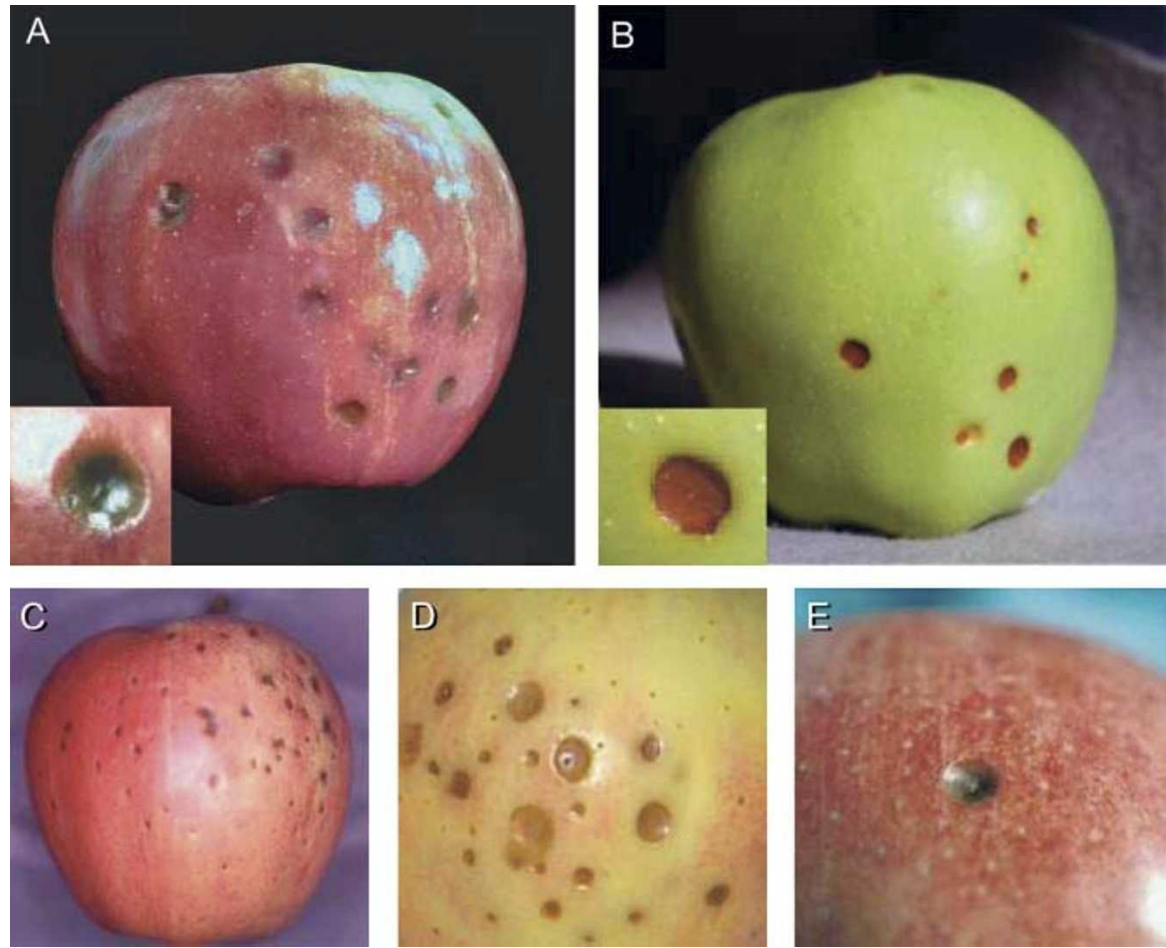

Fig. 1. Lenticel breakdown (LB) disorder on 'Gale Gala' (A), 'Golden Delicious' (B), 'Royal Gala' (C and D), and 'Imperial Gala' (E) apples. Insets in A and B show close-up of pitted lenticels.

corking of the cortex tissue is evident, and 6 ) there is a cavity underlying the sunken pit. It is different from jonathan spot and lenticel spot in that pitting is always present and usually progressive with increased time in storage.

Although prevalent on 'Gala' apples, especially 'Royal Gala', LB has also been observed on 'Fuji', and to a lesser degree on 'Granny Smith', 'Golden Delicious' (Fig. 1B), and 'Delicious'. Early symptoms on packed fruit from regular atmosphere (RA) storage are visible in angled light as slight indentations in the epidermis about 1 to $2 \mathrm{~mm}$, usually symmetrical and centered on a lenticel, without any darkening. With time, the depth of the dimple increases and the pit often becomes progressively darker. The darkening appears to be largely a function of how many layers of cells have desiccated, thereby compressing the cell walls, and the degree of phenolic browning therein. When a fully developed pit is sliced in half, a cavity is present commencing several cell layers beneath the hypodermis (Fig. 2). In severe cases, pits may overlap and appear coalesced. Generally, there is little corking in the cortex beneath the pit (Fig. 2C).
Initial studies were focused on poststorage processing, and a number of factors were identified that, if modified, could significantly reduce, but not eliminate, symptom expression (Curry, 2003). Importantly, this earlier work established that certain orchards (or blocks within orchards) showed no propensity for LB, whereas others were highly susceptible. Our efforts then focused on preharvest environment.

Previous studies showed that water vapor permeance of apple cuticle in storage was linked to cuticle microcracking (Maguire et al., 1999). This, together with our ensuing observation (E.A. Curry, unpublished data) that fruit subject to conditions of high desiccation potential during the final weeks of fruit enlargement had a greater propensity to develop $\mathrm{LB}$, led to the hypothesis that reducing water vapor permeance of the cuticle preharvest by applying a lipid-based, hydrophobic coating would reduce $\mathrm{LB}$ development on fruit in storage. Hydrophilic and lipophilic edible films and coatings have been shown to alter food moisture content (Debeaufort et al., 1998; Hagenmaier and Shaw, 1990; Kester and Fennema, 1989; Morillon et al., 2002; Quezada-Gallo et al., 2000).
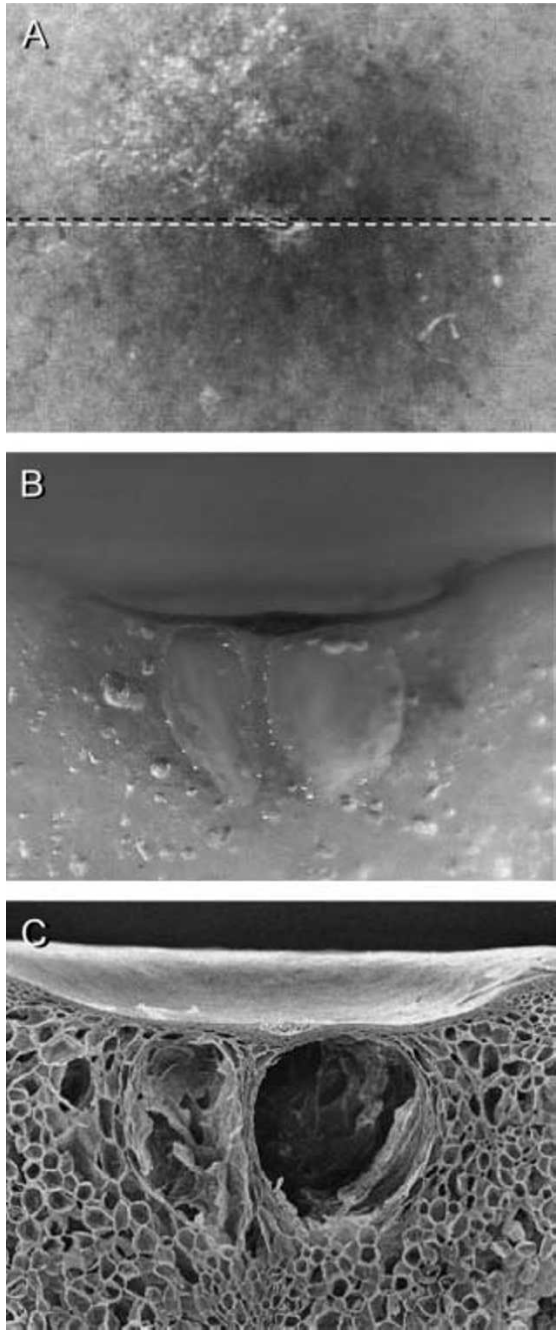

Fig. 2. Pitted lenticel (similar in size to that shown in Fig. 1E) from a 'Royal Gala' apple viewed perpendicular to the fruit surface (A). Dashed line indicates that fruit flesh was cut vertically through the center of the pit with a single-edged razor to show one-half of the pit in water (B), and the other half of the pit freeze-dried and examined using scanning electron microscopy (C). Micrograph in $\mathrm{C}$ is a digital mirror image to correspond with the picture in B.

Our objective in this series of trials was to determine if preharvest topical application(s) of lipophilic coatings would reduce the incidence and/or severity of LB in 'Gala' apples in RA storage.

\section{Materials and methods}

Trials were conducted over two crop seasons in Washington State and one in Chile, in commercial orchards that had had a history of LB for several years. In addition to an untreated control, treatments included 
the following three products manufactured by Pace International (Seattle, WA): 1) 2.5\% EpiShield ${ }^{\mathrm{TM}}$, a concentrated emulsifiable mixture of plant extracts and vegetable esters; 2) $1.5 \%$ PrimaFresh ${ }^{\circledR} 50-\mathrm{V}$, an emulsifiable concentrate of blended vegetable oils; and 3) 5\% Natural Shine $^{\mathrm{TM}} 9000$, an emulsifiable concentrate of carnauba wax. None of the orchards used in these experiments had overtree irrigation or cooling, nor was there any measurable precipitation during or after treatment applications.

2005-06, CHELAN, WASHINGTON. A block of 8-year-old 'Imperial Gala' /'Malling 106' ('M.106') trees on sandy loam was used from which comparable trees were preselected for similar crop load and vigor. Treatments were arranged in a completely randomized design with six replicates of three trees. Formulations were mixed on site in $\approx 100 \mathrm{~L}$ of water and applied to runoff $\mathrm{l} \mathrm{d}$ before harvest (on 31 Aug.) using a variable-pressure hand-held nozzle operating at about $2 \mathrm{~L} \cdot \mathrm{min}^{-1}$.

2006-07, MALAGA, WASHINGTON. An orchard block of 7-year-old 'Gale Gala' /'M.106' trees on sandy loam was used from which comparable trees were preselected for similar crop load and vigor. Treatments were arranged in a complete randomized design with six replicates of three trees. Formulations were mixed on site and applied as previously described 1 week before harvest (single treatment applied on 24 Aug.) or weekly beginning 3 weeks before harvest (three successive applications applied on 17, 24, and 31 Aug.).

2007, Linares, ChILE. Formulated treatments were applied to a uniform block of 9-year-old 'Royal Gala'/seedling, to runoff, using a commercial airblast sprayer at a volume of $\approx 1900 \mathrm{~L} \cdot \mathrm{ha}^{-1}$ l week before harvest (single application on 13 Feb.) or weekly starting 4 weeks before harvest (four treatments applied on 23 and 30 Jan., and 6 and 13 Feb.). Treatments were arranged in a complete randomized design with six replicates of three trees per replicate.

SAMPLE COLLECTION AND Quality eValuation. Fruit from the first trial was collected the day after treatment, whereas fruit from the two subsequent trials was collected about $7 \mathrm{~d}$ after the last application, which preceded commercial harvest by 1 to 2 d. Seventy apples were collected from each replication and were transported to the laboratory, of which 60 were placed on fiber trays in cardboard boxes and kept in RA storage at $-1{ }^{\circ} \mathrm{C}$ for poststorage evaluation. At 0,90 , and $180 \mathrm{~d}$ at $-1^{\circ} \mathrm{C}$ plus $24 \mathrm{~h}$ at $23^{\circ} \mathrm{C}, 10$ fruit from each replication were evaluated for fruit quality.

Internal ethylene concentration (IEC) was measured by inserting an 18-gauge needle equipped with a rubber septum through the fruit calyx into the central cavity and withdrawing $0.5 \mathrm{~mL}$ of core gas. Ethylene was measured using a gas chromatograph (model 5880A; Hewlett Packard, Avondale, PA) equipped with a 1-m Poropak $^{\circledR}$ (Waters Corp., Milford, MA) Q column according to standard protocols for flame ionization detection. Ground color was measured with a ColorFlex (model 45/0; Hunter Laboratories, Reston, VA) using the Hunter $\mathrm{L}^{*}, \mathrm{a}^{*}, \mathrm{~b}^{*}$ system, and the hue angle $(h)$ calculated. Firmness was measured at two locations per fruit, after removing the peel to a depth of $\approx 2 \mathrm{~mm}$, with a Texture Analyzer (TA-XT2; Texture Technologies, Scarsdale, NY) equipped with an 11.1-mm probe. Starch conversion was assessed using a scale of 1 to 6 with $6=$ no starch remaining.

At 90 and $180 \mathrm{~d}$ in RA storage, an additional 20 apples per replicate were subjected to a small-scale pilot packing line to induce LB. First, cold fruit were submerged in a $33^{\circ} \mathrm{C}$ water bath for $5 \mathrm{~min}$. Immediately thereafter, fruit were placed on a smallscale research packing line and conveyed through a soap wash, cool water rinse, wax treatment, brush polisher, warm air dryer, and were then placed on trays in cardboard boxes and returned to $-1{ }^{\circ} \mathrm{C}$ for $48 \mathrm{~h}$. Fruit were removed from the cold and left on open trays at $23{ }^{\circ} \mathrm{C}$ for $24 \mathrm{~h}$ before evaluation. LB was assessed simply by counting the number of discrete, lenticel-centered pits within a $2-\mathrm{cm}$ diameter ring placed over the most severely affected area of the fruit. Data are presented as the percentage of fruit with LB symptoms and/or the number of discrete pits per square centimeter surface area per apple.

Statistical analysis. Statistics were performed using Systat 11
(Systat Software, San Jose, CA). Normally distributed data were subjected to analysis of variance and means were separated using Tukey's Studentized range test (HSD). Data not normally distributed [mean LB incidence (\%), mean LB severity (pits $\left.\left./ \mathrm{cm}^{2}\right)\right]$ were subjected to the Kruskal-Wallis test. Differences among treatment means were assessed at $P \leq 0.05$.

Fruit Surface examination USING SCANNING ELECTRON MICROSCOPY (SEM). In 2006-07, additional fruit were also collected for the evaluation of treated cuticular surfaces. Apples were picked by the stem and calyx and were placed snuggly into foam trays with the longitudinal side of the fruit perpendicular to the alley, outward. These were placed in RA storage until further examination. At 0,90 , and $180 \mathrm{~d}$ after storage, peel tissue from three similar fruit was excised for evaluation by SEM. Sample preparation was similar to the method by Curry (2005) with the following modifications. Untouched portions of cuticle $\approx 4$ to $5 \mathrm{~mm}$ in diameter and $0.2 \mathrm{~mm}$ thick were shaved by hand about midway between the stem and the equator, just proximal to the widest part of the fruit, using a $0.012-\mathrm{mm}$-thick double-edge stainless steel razor previously rinsed with acetone and airdried to remove any residual oil. Samples were taken from the side facing the alley. The shaved cuticle section was fixed to a $24-\mathrm{mm}$ aluminum stub using double-sided carbon tape by pressing the edges of the entire section onto the tape using a pair of fine-tipped tweezers under a stereomicroscope. The stub was placed in a small, glass vacuum desiccator containing packaged silica gel and kept at $10^{\circ} \mathrm{C}$ and $1.3 \mathrm{kPa}$ for $24 \mathrm{~h}$ or until further treatment. Before SEM evaluation, mounted tissue was coated with platinum using a Desk II cold sputter coater (Denton Vacuum, Morristown, NJ) fitted with a tilting omni-rotating head. With the sample $47 \mathrm{~mm}$ from the platinum target, a coating thickness of $\approx 20 \mathrm{~nm}$ was achieved after $75 \mathrm{~s}$ at 40 milliamps and 2.6 Pa. Coated samples were kept in a vacuum desiccator and held under low vacuum at $1.3 \mathrm{kPa}$ and $10{ }^{\circ} \mathrm{C}$ until they were microscopically examined using a scanning electron microscope (Vega-II model 5136LM; Tescan, Brno, Czech Republic) 
equipped with secondary and backscattered electron detectors. Unless otherwise noted, images were obtained at $10 \mathrm{kV}$ and $7.4 \mathrm{mPa}$.

\section{Results}

2005-06, CHELAN, WASHINGTON. Fruit from this site developed severe $\mathrm{LB}$ after 90 and $180 \mathrm{~d}$ storage at $-1{ }^{\circ} \mathrm{C}$ plus simulated packinghouse processing. Although incidence was comparable between treatments, the percentage of fruit exhibiting symptoms was lowest for the EpiShield ${ }^{\mathrm{TM}}$ treatment (Table 1). Normally, symptom expression increases with time in storage; however, in this trial, maximum expression occurred after $90 \mathrm{~d}$ in RA, and no increase was measurable at $180 \mathrm{~d}$ (data not shown). Fruit quality attributes were no different among treatments (data not shown). These preliminary data suggested that preharvest application of certain lipophilic formulations could reduce the number of fruit expressing LB after storage plus processing.

2006-07, MALAGA, WASHINGTON. Although incidence of LB on fruit at this location was lower than in years prior, almost $20 \%$ of untreated fruit in RA storage for $180 \mathrm{~d}$ were deemed unmarketable due to presence of one or more dark pitted

Table 1. Effect of a single aqueous application of proprietary lipid formulations administered by a low-pressure hand gun to whole 'Imperial Gala' 'M.106' apple trees $1 \mathrm{~d}$ before harvest (31 Aug. 2005) in Chelan, WA, on expression of lenticel breakdown (LB) after $90 \mathrm{~d}$ of storage at $-1{ }^{\circ} \mathrm{C}\left(30.2^{\circ} \mathrm{F}\right)$.

\begin{tabular}{lcc}
\hline Treatment $^{\mathrm{x}}$ & Mean LB incidence (\%) & Mean LB severity $\left(\text { pits } / \mathrm{cm}^{2}\right)^{\mathrm{y}}$ \\
\hline Control $_{2.5 \% \text { EpiShield }}^{\mathrm{TM}}$ & $83 \mathrm{a}^{\mathrm{x}}$ & $1.6 \mathrm{a}$ \\
$1.5 \%$ PrimaFresh $^{\circledR} 50-\mathrm{V}$ & $65 \mathrm{~b}$ & $1.4 \mathrm{ab}$ \\
$5 / 0 \%$ Natural & $81 \mathrm{a}$ & $1.3 \mathrm{~b}$ \\
Shine $^{\mathrm{TM}} 9000$ & $76 \mathrm{ab}$ & $1.4 \mathrm{ab}$
\end{tabular}

${ }^{{ }^{2} \text { EpiShield }}{ }^{\mathrm{TM}}$, PrimaFresh ${ }^{\circledast} 50-\mathrm{V}$, and Natural Shine ${ }^{\mathrm{TM}} 9000$ are products of Pace International (Seattle, WA). ${ }^{\mathrm{y}} \mathrm{pit} / \mathrm{cm}^{2}=6.4516 \mathrm{pits} / \mathrm{inch}^{2}$.

Values within a column with the same letter are not significantly different at $P \leq 0.05$ using the Kruskal-Wallis test for nonparametric distribution.

lenticels (Table 2). Similar to the previous year's study, most of the LB (17\%) was present after $90 \mathrm{~d}$ in storage.

Using a single application 1 week before harvest, only 5\% Natural Shine ${ }^{\mathrm{TM}} 9000$ resulted in fruit with less LB after $90 \mathrm{~d}$ in storage; however, after $180 \mathrm{~d}$, there was no difference from the control. Whereas a single application of 1.5\% PrimaFresh ${ }^{\circledR} 50$-V showed an incidence of $10.8 \%$ after $90 \mathrm{~d}$ in storage, which was not significantly different from the control, LB incidence with this treatment did not increase as did the other treatments. Using three preharvest applications, all treated fruit after $90 \mathrm{~d}$ in storage showed LB incidence $\leq 70 \%$ of the untreated controls (Table 2). Although incidence increased after an additional $90 \mathrm{~d}$ in storage, reduction in LB ranged from $41 \%$ to $65 \%$ of untreated controls. There was no significant difference in the percentage of fruit with LB among fruit receiving applications of any of the formulations within a sampling date.

EFFECT OF TREATMENT ON FRUIT QUALITY. Although there were no differences among treatments on fruit quality at harvest, some

Table 2. Effect of treatment and number of applications of proprietary lipid formulations applied in 2006 to whole 'Gale Gala' /'M.106' apple trees in Malaga, WA, on apple fruit quality and incidence of lenticel breakdown (LB) after 90 or $180 \mathrm{~d}$ of storage at $-1{ }^{\circ} \mathrm{C}\left(30.2^{\circ} \mathrm{F}\right)$. Treatments were applied using a low-pressure handgun. Multiple applications were applied weekly beginning 3 weeks before harvest (17 Aug.), whereas the single application was applied 1 week before harvest (31 Aug.).

\begin{tabular}{|c|c|c|c|c|c|c|}
\hline Treatment $^{\mathrm{z}}$ & $\begin{array}{c}\text { Time in } R A \\
(d)^{y}\end{array}$ & $\begin{array}{c}\text { Applications } \\
\text { (no.) }\end{array}$ & $\begin{array}{c}\text { IEC } \\
\left(\mu \mathrm{L} \cdot \mathrm{L}^{-1}\right)^{\mathrm{x}}\end{array}$ & $\begin{array}{l}\text { Fruit } \\
\text { firmness } \\
(\text { lbf })^{w}\end{array}$ & $\begin{array}{c}\text { Soluble } \\
\text { solids } \\
(\%)\end{array}$ & $\begin{array}{c}\text { LB } \\
\text { incidence } \\
(\%)\end{array}$ \\
\hline Control & 90 & - & $24.1 \mathrm{~d}^{\mathrm{v}}$ & $15.6 \mathrm{a}$ & $13.2 \mathrm{a}$ & $16.7 \mathrm{a}$ \\
\hline $1.5 \%$ PrimaFresh $^{\circledR} 50-\mathrm{V}$ & & & $59.0 \mathrm{c}$ & $15.1 \mathrm{~b}$ & $13.0 \mathrm{a}$ & $10.8 \mathrm{ab}$ \\
\hline $5.0 \%$ Natural Shine ${ }^{\mathrm{TM}} 9000$ & & & $39.6 \mathrm{~cd}$ & $15.0 \mathrm{bc}$ & $12.6 \mathrm{~b}$ & $4.6 \mathrm{~b}$ \\
\hline $2.5 \%$ EpiShield $^{\mathrm{TM}}$ & & 3 & $85.0 \mathrm{~b}$ & $14.4 \mathrm{~d}$ & $13.1 \mathrm{a}$ & $5.0 \mathrm{~b}$ \\
\hline $5.0 \%$ Natural Shine $\mathrm{T}^{\mathrm{TM}} 9000$ & & & $122.4 \mathrm{a}$ & $14.3 \mathrm{~d}$ & $13.0 \mathrm{a}$ & $5.0 \mathrm{~b}$ \\
\hline Control & 180 & - & $157.7 \mathrm{c}$ & $13.1 \mathrm{a}$ & $12.7 \mathrm{ab}$ & $19.2 \mathrm{ab}$ \\
\hline $2.5 \%$ EpiShield $^{\mathrm{TM}}$ & & 1 & $144.8 \mathrm{c}$ & $13.1 \mathrm{a}$ & $12.8 \mathrm{a}$ & $14.2 \mathrm{ab}$ \\
\hline $1.5 \%$ PrimaFresh ${ }^{\circledR} 50-\mathrm{V}$ & & & $162.0 \mathrm{c}$ & $13.0 \mathrm{ab}$ & $12.5 \mathrm{ab}$ & $9.6 \mathrm{~b}$ \\
\hline $5.0 \%$ Natural Shine $\mathrm{T}^{\mathrm{TM}} 9000$ & & & $271.7 \mathrm{a}$ & $12.8 \mathrm{ab}$ & $12.3 \mathrm{~b}$ & $14.2 \mathrm{ab}$ \\
\hline $2.5 \%$ EpiShield $^{\mathrm{TM}}$ & & 3 & $269.5 \mathrm{a}$ & $12.6 \mathrm{bc}$ & $12.3 \mathrm{~b}$ & $10.8 \mathrm{~b}$ \\
\hline
\end{tabular}

${ }^{z}$ EpiShield ${ }^{\mathrm{TM}}$, PrimaFresh ${ }^{\circledR} 50-\mathrm{V}$, and Natural Shine ${ }^{\mathrm{TM}} 9000$ are products of Pace International (Seattle, WA).

${ }^{\mathrm{y} A} \mathrm{RA}=$ regular atmosphere storage.

${ }^{\mathrm{I}} \mathrm{IEC}=$ internal ethylene concentration; $1 \mu \mathrm{L} \cdot \mathrm{L}^{-1}=1.0 \mathrm{ppm}$

${ }^{\mathrm{w}} \mathrm{l} \mathrm{lbf}=4.4482 \mathrm{~N}$

"Values within a column with the same letter are not significantly different at $P \leq 0.05$ using Tukey's Studentized range test (HSD) for normally distributed data (IEC, fruit firmness, and soluble solids) or the Kruskal-Wallis test for nonparametric distribution (LB incidence). 
treatment effects were observed as time in storage increased. After $90 \mathrm{~d}$ at $-1{ }^{\circ} \mathrm{C}$, fruit with three applications had higher IEC than those untreated or those receiving a single application (Table 2). Generally, fruit firmness followed this same ripening pattern, with the control and the single application and lowest lipid content treatment being the most firm and three applications being less firm. Differences in percentage of soluble solids were minor. After $180 \mathrm{~d}$ at $-1{ }^{\circ} \mathrm{C}$, similar patterns persisted, generally with less difference and variance among treatment means. Ground color was unaffected by treatment (data not shown).

Fruit surface examination USING SEM. At harvest and after 90 and $180 \mathrm{~d}$ in storage, cuticle samples from fruit receiving different treatments were examined using SEM. Representative images of cuticular surfaces from untreated fruit as well as from those receiving multiple applications of each treatment are shown in Figs. 3 and 4 . The view field in Fig. 3A is $1.0 \mathrm{~mm}$. Typical of fruit growing in arid regions, the fruit epicuticle shows significant microcracking. Magnification of the inset shows a lenticel with microcracking in various stages of "healing" (Fig. 3B). Because formulation and concentration varied among treatments, examination of treated surfaces was completed to understand more fully the nature of the coatings in relation to the cuticular surface. Figure 4 shows cuticle plus lenticels from fruit surfaces 1 week after the third application of each respective treatment. Magnification for all images is identical. Fruit surfaces treated with EpiShield ${ }^{\mathrm{TM}}$ $(2.5 \%)$ and Natural Shine ${ }^{\mathrm{TM}} 9000$ $(5.0 \%)$ indicated a somewhat thicker and hardened coating that has continued to crack with fruit expansion (Fig. 4, A and C). On the other hand, $1.5 \%$ PrimaFresh ${ }^{\circledR} 50-\mathrm{V}$ shows more melding of the applied material with the cuticle. Examination of fruit surface at 90 or $180 \mathrm{~d}$ in RA storage showed little difference, with regards to coating, than that observed at harvest (data not shown). Fruit surfaces receiving a single application were also similar to those receiving three applications, though less thick (data not shown). Where the coating was excessively thick, such as that for three applications of $5 \%$ Natural Shine ${ }^{\mathrm{TM}}$
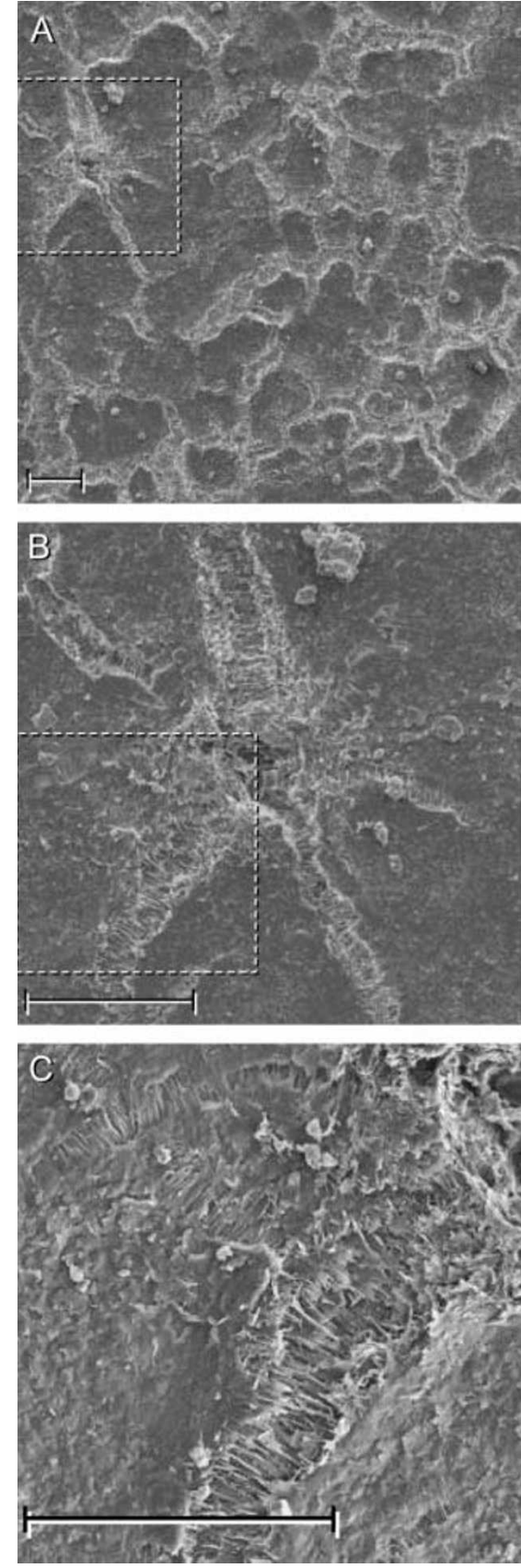

Fig. 3. Scanning electron micrographs of surface of untreated 'Gale Gala' apple at harvest. Field of view (A) is about $1.0 \mathrm{~mm}^{2}\left(0.00155 \mathrm{inch}^{2}\right)$ and shows normal cuticular microcracking due to fruit enlargement.

Magnification of inset in A indicated by the dashed line shows a lenticel in the process of cracking and healing (B). Magnification of inset in $B$ indicated by the dashed line shows typical microcrack "healing." The bar in each image represents $100 \mu \mathrm{m}$ (100 microns).

9000, SEM examination revealed fewer wax platelets protruding through the thickened build up after $90 \mathrm{~d}$ RA (data not shown).
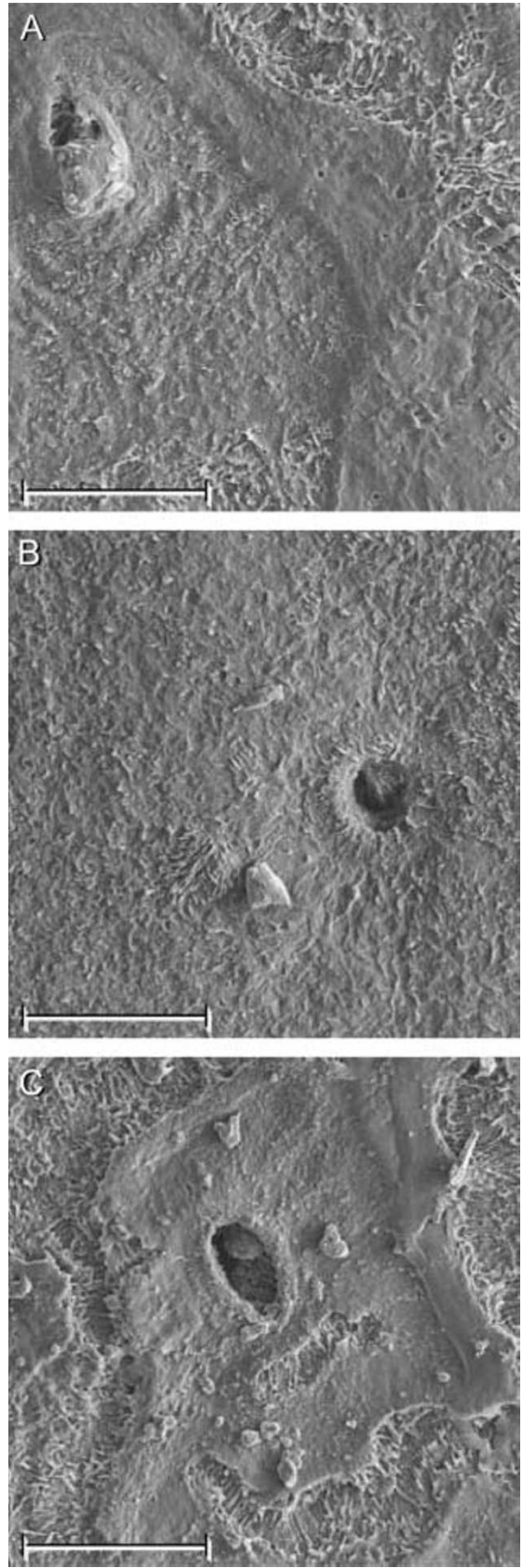

Fig. 4. Scanning electron micrographs of 'Gale Gala' apple peel tissue sampled 1 week after the third weekly application in 2006. The following treatments, manufactured by Pace International (Seattle, WA), were applied to whole 'Gale Gala' / Malling 106' apple trees with a low-pressure handgun: $2.5 \%$ EpiShield $^{\mathrm{TM}}$ (A), 1.5\% PrimaFresh $^{\circledR}$ 50-V (B), and 5\% Natural Shine ${ }^{\mathrm{TM}} 9000$ (C). The bar in each image represents $100 \mu \mathrm{m}(100$ microns).

2007, LINARES, CHILE. Differences among treatments were apparent after $90 \mathrm{~d}$ in RA. With a single application, only $2.5 \%$ EpiShield $^{\mathrm{TM}}$ 
resulted in fewer fruit with LB (Table $3)$. Using four applications, all treatments resulted in fruit with less LB ranging from $48 \%$ to $61 \%$ of the control; there was no difference among values for treated fruit. Evaluation of fruit quality at $90 \mathrm{~d}$ RA storage indicated no significant treatment effects on measured parameters (data not shown). To minimize additional treatment factors, fruit were not treated with pre- or postharvest fungicide. This resulted in $60 \%$ of the fruit exhibiting sufficient rot after $180 \mathrm{~d}$ in RA as to be unusable for further evaluation.

\section{Discussion}

As in other tree fruit, the apple maintains a cuticle to protect the inner cells from desiccation, contamination, and excessive water absorption. Wax biosynthesis, the basis of cuticle development, begins as soon as the epidermal cells sense desiccation pressure and continues through storage until cell necrosis (Belding et al., 1998; Morice and Shorland, 1973; Veraverbeke et al., 2005).

As the fruit enlarges, the cuticle also grows by "shearing" or "cracking" to accommodate the expansion (Faust and Shear, 1972; Meyer, 1944). Hypodermal cells may undergo mitosis and also stretch in the direction of enlargement, whereas epidermal cells mainly divide to maintain minimal surface area per cell (E.A. Curry, unpublished data). The cutin and the waxy surface undergo microcracking in which there occurs a simultaneous "tearing" of the cutin/ wax matrix and "repairing" with wax platelet regrowth. Under optimal conditions, this process allows the cuticle to enlarge while still maintaining protection against cell desiccation. However, under conditions of rapid fruit enlargement, high ambient temperature, and low relative humidity, "repairing" of the microcracks may lag fruit enlargement. Under such conditions, cells closest to the microcracks may tear and/or desiccate beyond the point of recovery. Lenticels are often the source of multiple microcracks (Fig. 3) that may further stress or induce injury to underlying cells, leading to desiccation pre- and postharvest (Maguire et al., 1999). We assume the lipophilic applications reduce subcuticular cell damage by covering or filling in some of the microcracks to prevent moisture loss and possible desiccation-induced necrosis.

Some of the variability of response between seasons is presumed due to differences in cultural and environmental factors. In addition, cultivars differ in surface wax morphology and chemical composition during development as well as during and after cold storage and subsequent shelf life (Curry, 2005; Veraverbeke et al., 2001). Characteristics and composition of apple cuticular wax also change in response to chemicals (Curry, 2008), as well to environmental stresses such as rain acidity (Rinallo and Mori, 1996), temperature (Roy et al., 1994; Lurie et al., 1996), and radiation (Kasperbauer and Wilkinson, 1995).

In 2006, we initially selected an additional site as a candidate for

Table 3. Effect of treatment and number of applications of proprietary lipid formulations applied in Linares, Chile, in 2007 on expression of lenticel breakdown (LB) in 'Royal Gala' apples after $90 \mathrm{~d}$ of storage at $-\mathrm{I}^{\circ} \mathrm{C}\left(30.2^{\circ} \mathrm{F}\right)$. Treatments were applied using a commercial airblast sprayer at a volume of about $1900 \mathrm{~L} \cdot \mathrm{ha}^{-1}$ (203.1 gal/acre). Multiple applications were applied weekly beginning 4 weeks before harvest ( 23 Jan.). The single application was applied 1 week before harvest (13 Feb.).

\begin{tabular}{|c|c|c|}
\hline Treatment $^{\mathrm{z}}$ & $\begin{array}{l}\text { Applications } \\
\text { (no.) }\end{array}$ & $\begin{array}{c}\text { Mean LB incidence } \\
(\%)\end{array}$ \\
\hline Control & - & $12.2 \mathrm{a}^{\mathrm{y}}$ \\
\hline 2.5\% EpiShield ${ }^{\mathrm{TM}}$ & 1 & $6.2 \mathrm{~b}$ \\
\hline $1.5 \%$ PrimaFresh $^{\circledR} 50-\mathrm{V}$ & & $10.0 \mathrm{a}$ \\
\hline $5.0 \%$ Natural Shine ${ }^{\mathrm{TM}} 9000$ & & $11.2 \mathrm{a}$ \\
\hline 2.5\% EpiShield ${ }^{\mathrm{TM}}$ & 4 & $06.2 \mathrm{~b}$ \\
\hline $1.5 \%$ PrimaFresh ${ }^{\circledR} 50-\mathrm{V}$ & & $07.5 \mathrm{~b}$ \\
\hline $5.0 \%$ Natural Shine $\mathrm{T}^{\mathrm{TM}} 9000$ & & $05.8 \mathrm{~b}$ \\
\hline
\end{tabular}

treatment that was irrigated by overtree sprinklers. However, as the temperature rose and the irrigation system was used often to cool the fruit, it became obvious that the fruit surface was accumulating significant residue from the water (data not shown). Although the treatments may have had similar benefits for reducing incidence of $L B$, we decided this was a variable for which we had little control, and we opted to use an orchard with undertree irrigation instead.

Generally, multiple applications were more effective than single treatments for reducing incidence of LB. This may have more to do with the time of most severe desiccation pressure during the final month before harvest and the optimum time of application. Further work is needed to better understand the relationship of microclimate and application timing and dosage to maximize treatment efficacy.

\section{Literature cited}

Belding, R.D., S.M. Blankenship, E. Young, and R.B. Leidy. 1998. Composition and variability of epicuticular waxes in apple cultivars. J. Amer. Soc. Hort. Sci. 123:348-356.

Curry, E.A. 2003. Factors associated with lenticel breakdown in apples. Proc. Washington State Hort. Assn. 5 June 2008. $<$ http://postharvest.tfrec.wsu.edu/ REP2003B.pdf>.

Curry, E.A. 2005. Ultrastructure of epicuticular wax aggregates during fruit development in apple (Malus domestica Borkh). J. Hort. Sci. Biotechnol. 80:668-676.

Curry, E.A. 2008. Effects of 1-MCP applied postharvest on epicuticular wax of apples Malus domestica (Borkh.) during storage. J. Sci. Food Agr. 88:996-1006.

Debeaufort, F., J.A. Quezada-Gallo, B. Delporte, and A. Voilley. 1998. Edible films and coatings: Tomorrow's packagings: A review. Crit. Rev. Food Sci. Nutr. 38:299-313.

Faust, M. and C.B. Shear. 1972. Fine structure of the fruit surface of three apple cultivars. J. Amer. Soc. Hort. Sci. 97:351355 .

Hagenmaier, R.D. and P.E. Shaw. 1990. Moisture permeability of edible films made with fatty acid and (hydroxypropyl)methylcellulose. J. Agr. Food Chem. 38:1799-1803.

Kasperbauer, M.J. and R.E. Wilkinson. 1995. Mulch surface color affects 
accumulation of epicuticular wax on developing leaves. Photochem. Photobiol. Sci. 2:861-866.

Kester, J.J. and O. Fennema. 1989. An edible film of lipids and cellulose ethers: Barrier properties to moisture vapor transmission and structural evaluation. J. Food Sci. 54:1383-1389.

Lurie, S., E. Fallik, and J.D. Klein. 1996. The effect of heat treatment on apple epicuticular wax and calcium uptake. Postharvest Biol. Technol. 8:271277.

Maguire, K.M., A. Lang, N.H. Banks, A. Hall, D. Hopcroft, and R. Bennett. 1999. Relationship between water vapour permeance of apples and micro-cracking of the cuticle. Postharvest Biol. Technol. 17:89-96.

Meheriuk, M., R.K. Prange, P.D. Lidster, and S.W. Porritt. 1994. Postharvest disorders of apples and pears. Agr. Can. Publ. $1737 /$ E.

Meyer, A. 1944. A study of the skin structure of 'Golden Delicious' apples. Proc. Amer. Soc. Hort. Sci. 45:105-110.
Morice, I.M. and F.B. Shorland. 1973 Composition of the surface waxes of apple fruits and changes during storage. J. Sci. Food Agr. 24:1331-1339.

Morillon, V., F. Debeaufort, G. Blond, M. Capelle, and A. Voilley. 2002. Factors affecting the moisture permeability of lipid-based edible films: A review. Crit. Rev. Food Sci. Nutr. 42:67-89.

National Agricultural Statistical Service. 2007. Agri-Facts. 5 June 2008. <http:// www.nass.usda.gov/Statistics_by_State/ Washington/Publications/Agri-facts/ agriloct.pdf>.

Pierson, C.F., M.J. Ceponis, and L.P. McColloch. 1971. Market diseases of apples, pears, and quinces. U.S. Dept. Agr. Hdbk. No. 376:2-69.

Porritt, S.W., M. Meheriuk, and P. Lidster. 1982. Postharvest disorders of apples and pears. Agr. Can. Publ. 1737E:1153.

Quezada-Gallo, J.A., F. Debeaufort, F. Callegarin, and A. Voilley. 2000. Lipid hydrophobicity, physical state and distribution effects on the properties of emulsion-based edible films. J. Membr. Sci. 4678:1-10.

Rinallo, C. and B. Mori. 1996. Damage in apple (Malus domestica Borkh) fruit exposed to different levels of rain acidity. J. Hort. Sci. 71:17-23.

Roy, S., A.E. Watada, W.S. Conway, E.F. Erbe, and W.P. Wergin. 1994. Lowtemperature scanning electron microscopy of frozen hydrated apple tissues and surface organisms. HortScience 29: 305-309.

Veraverbeke, E.A., J. Lammertyn, B.M. Nicolai, and J. Irudayaraj. 2005. Spectroscopic evaluation of the surface quality of apple. J. Agr. Food Chem. 53:10461051.

Veraverbeke, E.A., J. Lammertyn, S. Saevels, and B.M. Nicolaï. 2001. Changes in chemical wax composition of three different apple (Malus domestica Borkh.) cultivars during storage. Postharvest Biol. Technol. 23:197-208. 